\title{
Developing Flexibility in Mental Arithmetic in Interactive- Cooperative Learning Situations: Interaction as an Occasion for Productive Learning Processes
}

\author{
Laura Korten \\ University of Münster, Münster, Germany
}

The article presents a design research study focusing on the encouragement and investigation of flexibility in mental calculation of elementary students. It is argued that the development of flexible mental calculation can occur in student-to-student interactive-cooperative learning situations. To investigate this idea, 14 pairs of German second and third graders (paired with and without learning difficulties) were observed solving and exploring addition tasks within a designed interactive teaching-learning arrangement. Transcripts of paired interactions were analyzed. Results show specific learning processes and fruitful 'productive moments' in the interactions, which occurred in every student-to-student pair. The results of this study about the existence of these 'productive moments' and the types of impulses that can lead to them can be recommended as a basis for didactical planning interactive activities to improve students' cognitive flexibility in mental arithmetic.

Keywords: flexible mental calculation, interactive-cooperative learning, heterogeneous learners

Teaching heterogeneous students with diverse learning abilities and experiences in mathematics classrooms has always been a challenge for German elementary school teachers. Nevertheless, student diversity can be viewed as an occasion to encourage productive interactive-cooperative learning situations, in which heterogeneous learners, with and without learning difficulties, benefit from sharing their various insights and knowledge. However, in Germany teaching mathematics in heterogeneous classes often takes place through separation or individualization, as noted by Korff (2015) who draws attention to the problem that interactive-cooperative learning situations are seldom encouraged in school practice. Teachers locate this problem more in mathematics classrooms - especially in arithmetic - than 
in other subjects because they believe that arithmetic contents offer only a few possibilities of an action-oriented and material-related access (Korff, 2015). Moreover, they are of the opinion, the abstract nature of arithmetic and its hierarchical structure makes it difficult for heterogeneous students to interact and learn with and from each other (Korff, 2015). Consequently, opportunities for interaction that lead to productive learning processes are not taken in German school practice, even though interaction processes can be beneficial for arithmetic learning, as will be pointed out in the theoretical framework of this article.

We know very little about interaction processes when heterogeneous learners share arithmetical insights and knowledge about arithmetical characteristics and relations, nor do we understand well the interactive learning processes associated with the development of flexible mental arithmetic. This gap in research and the related problem of German school practice motivated the current study to encourage and investigate the development of flexibility in mental arithmetic in interactive-cooperative learning situations with heterogeneous learners, some with learning difficulties.

\section{Theoretical Framework}

To address this problem, the study reported here draws on two distinct theoretical frameworks:

(1) Flexible mental calculation and the underlying learning processes that promote cognitive flexibility in mental calculation and

(2) Effective elements of student interactions that can promote cognitive flexibility in mental calculation.

Each will be briefly discussed.

\section{Flexible Mental Calculation}

In international comparative studies such as Trends in International Mathematics and Science Study (TIMSS), children repeatedly show only basic mathematical skills and fail to demonstrate more advanced and flexible arithmetical competencies even by the end of the fourth grade (Selter, Walter, Walther, \& Wendt, 2016). Furthermore, other empirical studies indicate that primary school learners prefer to use an automatic standard calculation method and written algorithms instead of flexibly using a more adequate method (Selter, 2000) and that learning these automatic computing algorithms does not support the development of flexible calculating (Klein \& Beishuizen, 1998; Torbeyns, De Smedt, Ghesquière \& Verschaffel, 2009). Early in the twenty-first century, flexible mental calculation became a central goal in the German primary school curriculum (Ministerium für Schule und Weiterbildung [MSW], 2008). At the same time, the development of flexible mental calculation competencies is a 'critical point' in every student's 
learning. In short, automatic standard calculation methods and error-prone counting strategies should be replaced with more beneficial flexible calculating strategies relating to structural and operational relations (HäselWeide \& Nührenbörger, 2012; Verschaffel, Luwel, Torbeyns, \& van Dooren, 2009).

Current literature offers different definitions of flexible calculation and interprets the aspects of 'flexibility', 'adaptivity', 'adequacy' and 'creativity' differently (cf. e. g., Rechtsteiner-Merz \& Rathgeb-Schnierer, 2016; Selter, 2009; Verschaffel et al., 2009). In most of the definitions, flexibility is understood as the ability to switch between different solution tools (RathgebSchnierer \& Green, 2013), while the aspect of adaptivity rather emphasizes the selection of the most appropriate strategy. In the study reported here, adaptivity is related to the recognition of problem characteristics, number patterns, and numerical relations, because various studies have shown that flexible student calculators rely on recognized characteristics and relations of numbers and problems (e. g., Rathgeb-Schnierer, 2006, 2010; Threlfall, 2009). Consequently I take the position that flexible mental calculating is a situationspecific and individual response to specific number and problem characteristics and relations and the corresponding construction of a solution process using strategic tools (following Rathgeb-Schnierer, 2006, 2010; Threlfall, 2002, 2009). This definition indicates that "[s]olving problems is a complex interaction between different [interrelated] domains" (RathgebSchnierer \& Green, 2013, p. 354): methods of calculation, cognitive elements, and tools for solution (see Figure 1).

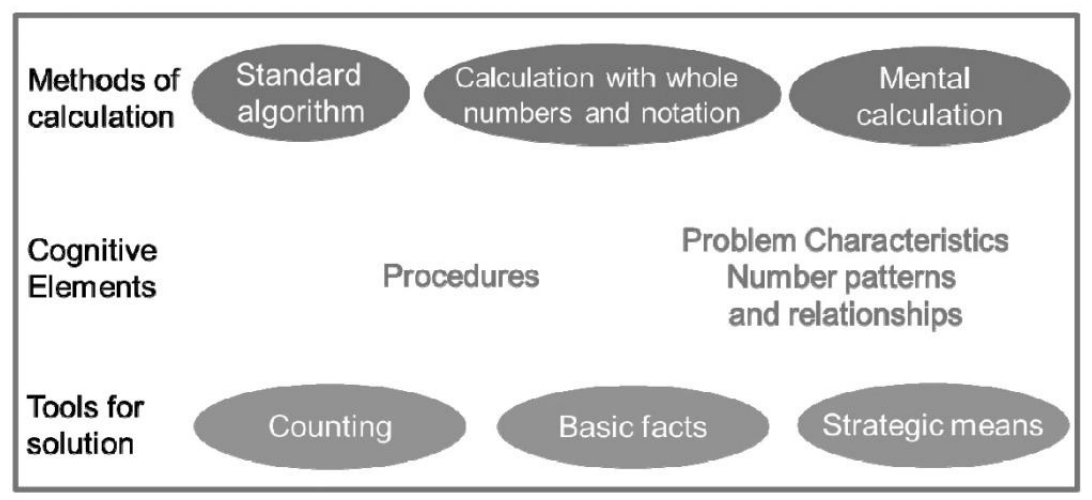

Figure 1. Domains of Calculation Process (Rathgeb-Schnierer \& Green, 2013).

Note. This figure of the Domains of Calculation Process was produced by E. Rathgeb-Schnierer, 2011 and translated by E. Rathgeb-Schnierer \& M. Green, 2013. Reprinted from "Flexibility in mental calculation in elementary students from different math classes," by E. Rathgeb-Schnierer \& M. Green, 2013, Proceedings of the Eighth Congress of the European Society for 
Research in Mathematics Education p. 354. Copyright 2013 by E. RathgebSchnierer and M. Green. Reprinted with permission.

Concerning these domains of the calculation process, the study presented in this article focuses only on additive 'mental calculation' concerning the methods of calculation (Figure 1, top row, right). Based on the definition of flexible calculating used here, the focus was on the domain of cognitive elements that encourage a perception of 'problem characteristics, number patterns, and relations' (Figure 1, middle row, right). The corresponding focus on tools for solution lies in the corresponding construction of 'strategic means' (Figure 1, bottom row, right).

\section{Developing Cognitive Flexibility in Mental Calculation in Interactive- cooperative Learning Situations}

There is widespread agreement that interpersonal communication about arithmetical characteristics and relations plays an essential role in the development of flexible calculating competencies (e. g., Cobb, Yackel, \& Wood, 1992; Gaidoschik, 2010; Rathgeb-Schnierer, 2006). When such interaction is neglected, a generalization of operational characteristics and relations is made even more difficult (Gaidoschik, 2010). This is particularly true for children with learning difficulties (Lorenz, 2005).

On the one hand, student's own thoughts get - based on individual learning prerequisites like learning abilities and experiences - clarified, ordered, and presented understandably during the interaction (Korten, 2020, following Rathgeb-Schnierer, 2006). On the other hand, thoughts of others are understood and linked with one's own thoughts that a dispute with thoughts of others gets encouraged. It is by coordinating one's own thoughts with the dispute of the thoughts of others during an interaction that the development of flexible competencies is made possible (Korten, 2020, following RathgebSchnierer, 2006). Accordingly, a cycle of individual construction, interaction, reflection, and development can be encouraged, in which the interaction with the verbal statements and nonverbal actions of the interactors can be seen as a potential 'motor' of individual learning processes (Korten, 2020, following Rathgeb-Schnierer, 2006).

In this vein, Dekker and Elshout-Mohr (1998) investigated 'key activities' in students' mathematical interactions and their role in interactivecooperative mathematical problem-solving. The researchers distinguished between four different key activities: "to show one's work, to explain one's work, to justify one's work, [and] to reconstruct one's work" (Dekker \& Elshout-Mohr, 1998, p. 305). These activities have in common that they are implicated in successful mathematical learning during interaction. In the study presented here, these 'key activities' serve as indicators of productive interaction structures and as a reference to interactive learning processes (Figure 2, right). 'Key activities' are naturally stimulated by interactive impulses (Figure 2, left) and go hand-in-hand with 'mental activities' 
(Figure 2, middle), such as thinking and reflecting (Dekker \& Elshout-Mohr, 1998, p. 308). Figure 2 exhibits the interrelation of three elements, which arose from Dekker's and Elshout-Mohr's study (1998).

Impulse in the interaction (verbal or nonverbal), which can trigger a productive interaction.
,Key activities' are important for a productive interaction. They therefore serve as indicators of productive interaction and as a reference to interactive learning processes.

Figure 2. Potential Indicators of Productive Interaction Structures.

Note. Indicators of Productive Interaction Structures. Translated and reprinted from Gemeinsame Lernsituationen im inklusiven Mathematikunterricht Zieldifferentes Lernen am gemeinsamen Lerngegenstand des flexiblen Rechnens in der Grundschule (p. 217), by L. Korten, 2020, Springer Spektrum. Copyright 2020 by Springer Nature. Translated and reprinted with permission from Springer Nature and Copyright Clearance Center.

\section{Research Questions and Methodological Design}

The research reported here focuses on the encouragement and investigation of the development of flexibility in mental arithmetic in interactive-cooperative learning situations of heterogeneous learners. Three research questions were considered in this article to understand and investigate the encouraged learning and interaction processes:

(RQ1) How do individual flexible mental calculation processes develop during the encouraged interactive-cooperative learning situations?

(RQ2) Which interaction structures (e.g. interactive activities, intensity, symmetry, and references) can be observed during the encouraged interactive-cooperative learning situations?

(RQ3) To what extent is there an interrelation between the observed interaction structures and the development of individual and goaldifferentiated flexible mental calculation processes?

To answer these research questions, a design research approach with a focus on learning processes was chosen (Prediger, Gravemeijer, \& Confrey, 2015). With this approach, a teaching-learning arrangement was designed, tested, and improved by conducting design experiments in three iterative design research cycles (following Prediger et al., 2015). In each design research cycle, the teaching-learning arrangement was tested, and the encouraged learning processes and interaction processes, as well as their interrelation, were analyzed to answer the research questions. The designed 
teaching-learning arrangement incorporated specific means for the successful encouragement of interactive-cooperative learning situations, which got refined and improved in the course of the design research cycles. In this article, research questions (RQ1) and (RQ3) will be answered exclusively. In each of the design experiments (following Prediger et al., 2015) a heterogeneous pair of students (cf. theoretical sample below) worked largely independently on the tasks of investigating neighboring numbers and their sums.

The theoretical sample was comprised of 14 pairs of second and third graders (7-9 years old), from three German primary schools. Laboratory situations (partner work in simulated classroom situations) allowed researchers to learn more about students' thinking, their learning, and their interaction processes. Each design experiment took place in a pair setting with two heterogeneous learners from the same class: one child with and one child without learning difficulties. The participants were selected with the help of their teachers to find pairs of children who like each other. Furthermore, attention was paid to an equal distribution of male, female, and mixed couples, different heterogeneity ranges, and school backgrounds to approximately realizing a theoretical saturation by case contrasts and comparative analyses (Steinke, 2000). This means that findings are generated by selecting and analyzing different types of cases to enable contrasting case comparisons between them.

The heterogeneous pairs were audio and video recorded, with transcripts made of potentially productive moments in student interactions (for potential indicators of productive moments in the interaction see Figure 2). These transcripts depict the children's actions and utterances, which are 'objects of observation' and 'information carriers' for detailed analysis.

\section{Interpretative Analysis Approach and Analysis Instruments}

For the detailed analysis, an interpretative-epistemologically oriented analysis approach was chosen, which is based on different analysis instruments (by Dekker \& Elshout-Mohr, 1998; Krummheuer, 2010; Naujok 2000; Steinbring, 2005, 2015), to be able to reconstruct and investigate both the learning and the interaction processes.

For the purpose of this study, the adapted and extended epistemologically oriented analysis, according to Steinbring (2005, 2015), contributes to the reconstruction of the development of the individual and goal-differentiated flexible mental calculation processes that take place during the encouraged interactive-cooperative learning situations (RQ1). In his epistemological triangle, Steinbring $(2005,2015)$ assumes that mathematical signs and symbols need explanation and interpretation. Meaning must be attributed to them by an explanatory reference context. The mediation between sign/symbol and reference context is regulated by conceptual conditions (see Figure 3; Steinbring, 2005, 2015). 
If the mathematical conceptual conditions of one learner changes and leads to a new concept, this is - following the adopted version of the triangle for the here presented study (see Figure 3) - a sign for a situational development in the individual flexible mental calculation processes and consequently in the situational learning process of this learner (RQ1).

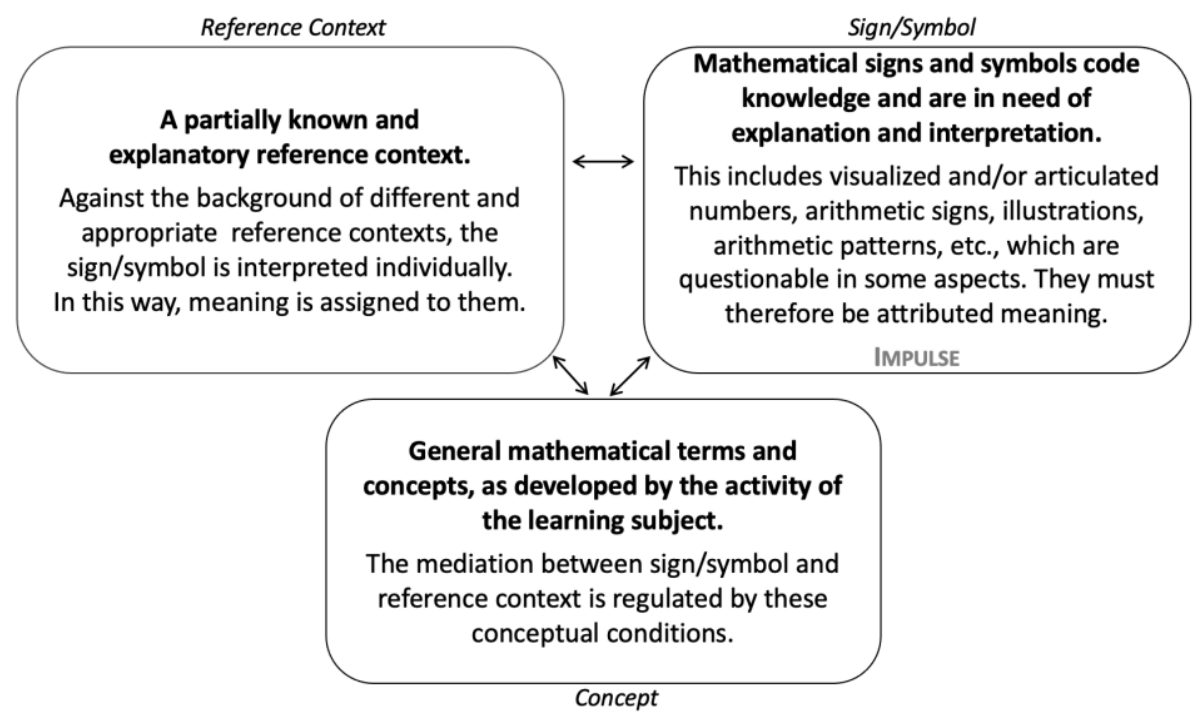

Figure 3. The Epistemological Triangle by Steinbring (2005, 2015), adapted and extended by the Impulse.

Note. The Epistemological Triangle by Steinbring $(2005,2015)$ adapted and extended by the Impulse. Translated and reprinted from Gemeinsame Lernsituationen im inklusiven Mathematikunterricht - Zieldifferentes Lernen am gemeinsamen Lerngegenstand des flexiblen Rechnens in der Grundschule (p. 211), by L. Korten, 2020, Springer Spektrum. Copyright 2020 by Springer Nature. Translated and reprinted with permission from Springer Nature and Copyright Clearance Center.

The epistemological triangle, according to Steinbring (2005, 2015), has been extended by the IMPULSE to reconstruct the interrelation between interaction structures and the development of individual flexible mental calculation processes (RQ3). Therefore, impulses were considered to trigger a focus on a new sign/symbol or a new interpretation (shown with a new reference context) of a previously focused sign/symbol.

To reconstruct and categorize a concept (Figure 3, bottom), such as the development of flexible mental calculation, a specialized model (Figure 4) has been derived from the model in Figure 1 and previous research (RathgebSchnierer \& Green, 2013; Rechtsteiner-Merz, 2013). As mentioned before, a 'solution process' is a situation-specific and individual response to specific 
'cognitive elements' (Figure 4, left; e. g. 'characteristics and relations of numbers and problems' or 'procedures') and the corresponding construction of the actual solution process using 'tools for solution' (Figure 4, right). In this sense, 'cognitive elements' are individual experiences, which comprise background-knowledge and - expertise for the individual solution process (Rathgeb-Schnierer \& Green, 2013; Rechtsteiner-Merz, 2013).

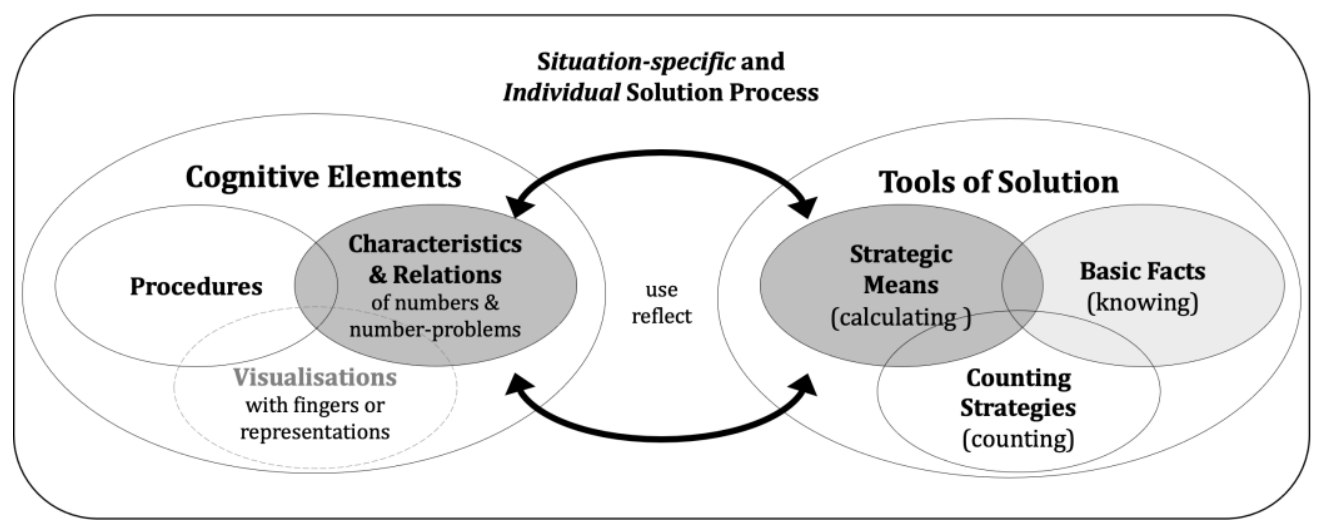

Figure 4. A Model to Reconstruct Children's Learning Paths (based on the model in Figure 1).

Note. A Model to Reconstruct Children's Learning Paths. Translated and reprinted from Gemeinsame Lernsituationen im inklusiven Mathematikunterricht - Zieldifferentes Lernen am gemeinsamen Lerngegenstand des flexiblen Rechnens in der Grundschule (p. 126), by L. Korten, 2020, Springer Spektrum. Copyright 2020 by Springer Nature. Translated and reprinted with permission from Springer Nature and Copyright Clearance Center.

Referring to the theoretical framework above, the dark grey fields in Figure 4 are indicators of flexible mental calculation competencies. Therefore, these two elements became the primary focus of the analysis:

- cognitive element (CE): the perception of characteristics and relations of numbers (development of numerical concepts) and addition problems as a basis for developing cognitive flexibility;

- tools of solution (TS): the use and reflection of these characteristics and relations for working out neighboring sums with the focus on 'strategic means' for calculating.

Additionally, the general

- strategic approach (SA) for searching for new neighboring numbers will be reconstructed as it might influence (CE) and (TS).

'Strategic means' for calculating as used here "are not holistic strategies or cognitive menus that complete a solution path; rather, they are distinct devices that can be combined in flexible ways to modify complex 
problems to make them easier" (Rathgeb-Schnierer \& Green, 2013, p. 355). This sense of 'strategic means' has been incorporated for this study to include:

- decomposing and composing (e. g. $12+13=10+10+2+3$ )

- transforming a problem, for example, by changing the summands in same or opposite directions (e. g. $6+17=7+16$ )

- deriving the solution from a known problem, for example, by using decadic analogy relations (e. g. if 4 joined with 3 is 7, 4 joined with 13 must be 17) (Rathgeb-Schnierer,2006; Rathgeb-Schnierer \& Green, 2013).

\section{Exemplary Analysis and Interpretation}

In this section, the interpretative analysis approach is illustrated with exemplary excerpts of an interactive-cooperative learning situation between Marina and Miriam, a pair of two heterogeneous learners, one child with and one child without learning difficulties. The girls explored diagonal neighboring numbers (see Figure 5) and their sums on the twenty-frame. (Assigned instruction in the individual phase: Find as many neighboring numbers and their sums as possible and write them down. Can you discover anything which helps you? Assigned instruction in the interactive-cooperative phase: Which neighbors and sums have you found? Collect and sort. Did you find all? Can you discover anything which helps you to find all and to add cleverly?)

\begin{tabular}{|c|c|c|c|c|c|c|c|c|c|}
\hline \multicolumn{3}{|c|}{ horizontal } & \multicolumn{3}{|c|}{ vertical } & \multicolumn{4}{|c|}{ diagonal } \\
\hline 1 & 2 & 3 & 4 & 5 & 6 & 7 & 8 & 9 & 10 \\
\hline 11 & 12 & 13 & 14 & 15 & 16 & 17 & 18 & 19 & 20 \\
\hline
\end{tabular}

Figure 5. Neighboring Numbers.

Note. Neighboring Numbers. Translated and reprinted from Gemeinsame Lernsituationen im inklusiven Mathematikunterricht - Zieldifferentes Lernen am gemeinsamen Lerngegenstand des flexiblen Rechnens in der Grundschule (p. 162), by L. Korten, 2020, Springer Spektrum. Copyright 2020 by Springer Nature. Translated and reprinted with permission from Springer Nature and Copyright Clearance Center.

In the following dialogue, the girls have discovered the equality of always two sums of the diagonal neighboring numbers (due to the constancy of sum by changing the summands equally in opposite directions, e. g., $8+19$ and 9+18) and have arranged the addition problems according to their discovery (see Table 1, line 1). In the following first scene, they found the problem $3+14=17$ but a second problem with the sum 17 is missing: 


\section{Table 1}

Dialogue between Marina and Miriam: First Scene

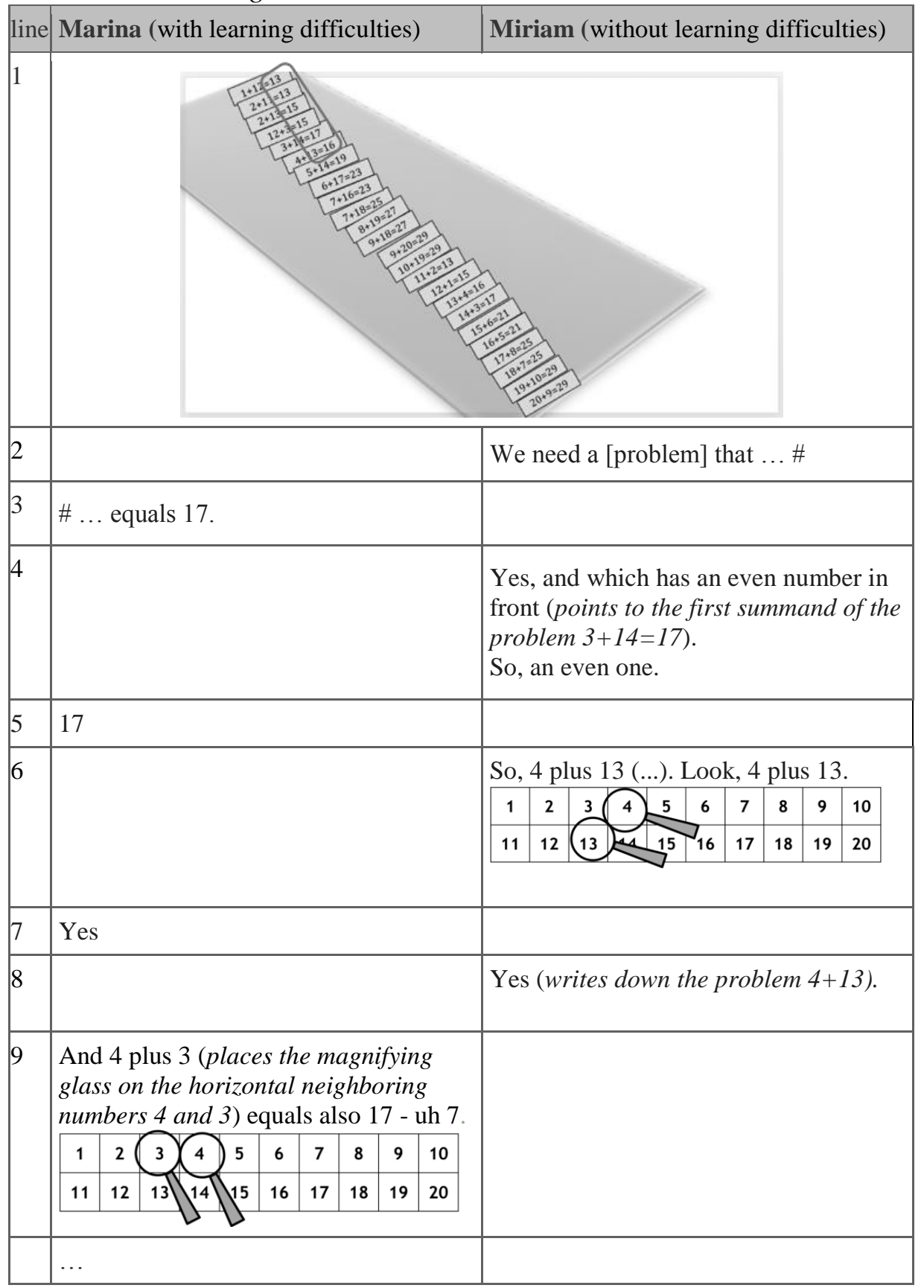

Note. Dialogue between Marina and Miriam: First Scene. Translated and reprinted from Gemeinsame Lernsituationen im inklusiven Mathematikunterricht - Zieldifferentes Lernen am gemeinsamen Lerngegenstand des flexiblen Rechnens in der Grundschule (p. 246), by L. Korten, 2020, Springer Spektrum. Copyright 2020 by Springer Nature. 
Translated and reprinted with permission from Springer Nature and Copyright Clearance Center.

In this scene, Miriam seemed to interpret the addition problem $4+13$ as the missing problem with the sum 17 and an even first summand (Table 1, lines 4 and 6). Miriam's interpretation became Marina's new sign/symbol, which needed explanation and interpretation (cf. Figure 6, sign/symbol, upper right). Marina's reaction to Miriam's assumption about the missing problem 4+13 is: "And 4 plus 3 [...] equals also 17 - uh 7" (Table 1, line 9). With this utterance, Marina refers to the horizontal neighboring numbers and appears to interpret the task $4+13=17$ as a problem with decadic analogy relations to the problem $4+3=7$ (cf. Figure 6, reference context, upper left). Her interpretation seems to be based on partial-whole relations $(13=3+10)$ and decadic analogy relations (if one summand changes by $+/-10$, the sum changes by $+/-10$ ). Marina, who has previously considered all numbers in isolation and solved addition problems only by counting, was beginning to perceive characteristics and relations of numbers and addition problems. Further scenes, which cannot be shown here in more detail, support this idea. Consequently, regarding flexible mental calculating, Marina showed evidence of advancing cognitive elements (CE) by the perception of new characteristics and relations (cf. Figure 6, concept). This further development was triggered by Miriam's interaction-action - in this case an assumption - against the background of Miriam's previous descriptions of arithmetical relations, which Marina copied from her partner (cf. Figure 6, IMPULSE, upper right).

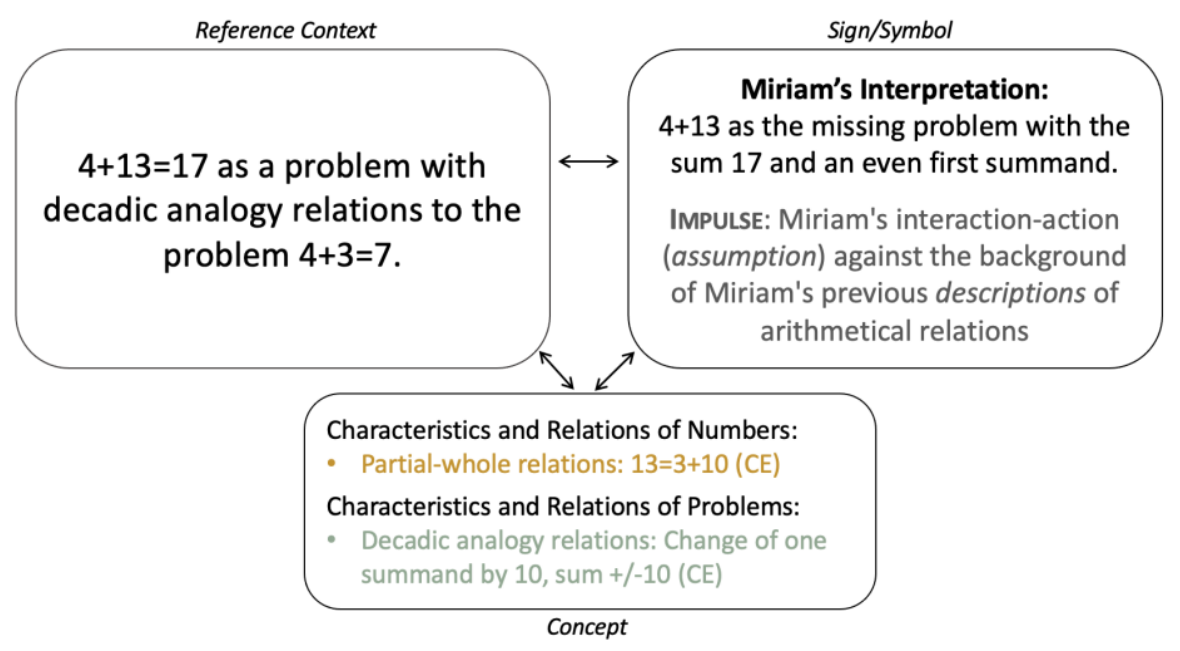

Figure 6. Marina's Interpretation I.

Note. Marina's Interpretation I. Translated, adapted without affecting the meaning and reprinted from Gemeinsame Lernsituationen im inklusiven Mathematikunterricht - Zieldifferentes Lernen am gemeinsamen Lerngegenstand des flexiblen Rechnens in der Grundschule (p. 251), by L. Korten, 2020, Springer Spektrum. Copyright 2020 by Springer Nature. 
Translated, adapted and reprinted with permission from Springer Nature and Copyright Clearance Center.

In a later phase, Marina reacted to the general task "Did you find all". She assumed that the sum 24 was missing and questioned the completeness of the diagonal sums of the twenty-frame:

\section{Table 2}

Dialogue between Marina and Miriam: Second Scene

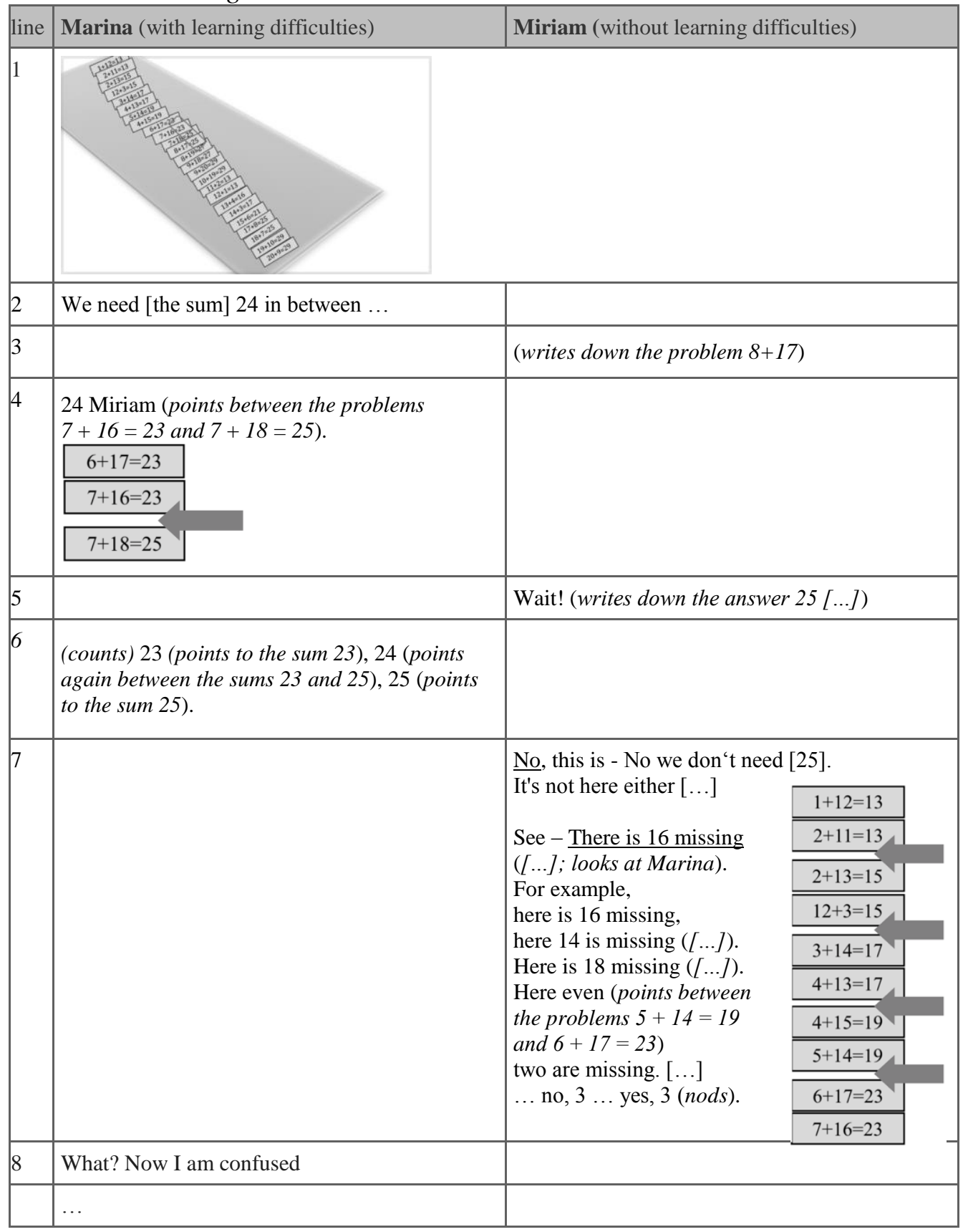


Note. Dialogue between Marina and Miriam: Second Scene. Translated and reprinted from Gemeinsame Lernsituationen im inklusiven Mathematikunterricht - Zieldifferentes Lernen am gemeinsamen Lerngegenstand des flexiblen Rechnens in der Grundschule (p. 252 f.), by L. Korten, 2020, Springer Spektrum. Copyright 2020 by Springer Nature. Translated and reprinted with permission from Springer Nature and Copyright Clearance Center.

In this scene, Marina seemed to interpret the sum 24 as a still missing sum in the position between the sum 23 (predecessor) and the sum 25 (successor) (cf. Table 2, lines 2, 4, 6; Figure 7, reference context, upper left). This interpretation was presumably based on the ordinal number aspect of the positions of individual sums and the knowledge about the numerical sequence of natural numbers. She used this knowledge of the system to question the completeness of their addition problems and came to the incorrect assumption that the sum 24 was missing (Table 2, lines 2, 4, 6). Here the development of her strategic approach for searching (SA) was reconstructed because previously Marina had preceded arbitrarily, but her subsequent searching was based on numerical characteristics (cf. Figure 7, concept). This development was triggered by the wording of the task ("Did you find all?") against the background of Miriam's previous descriptions of her strategic approach for searching oriented on sums (cf. Figure 7, IMPULSE, upper right).

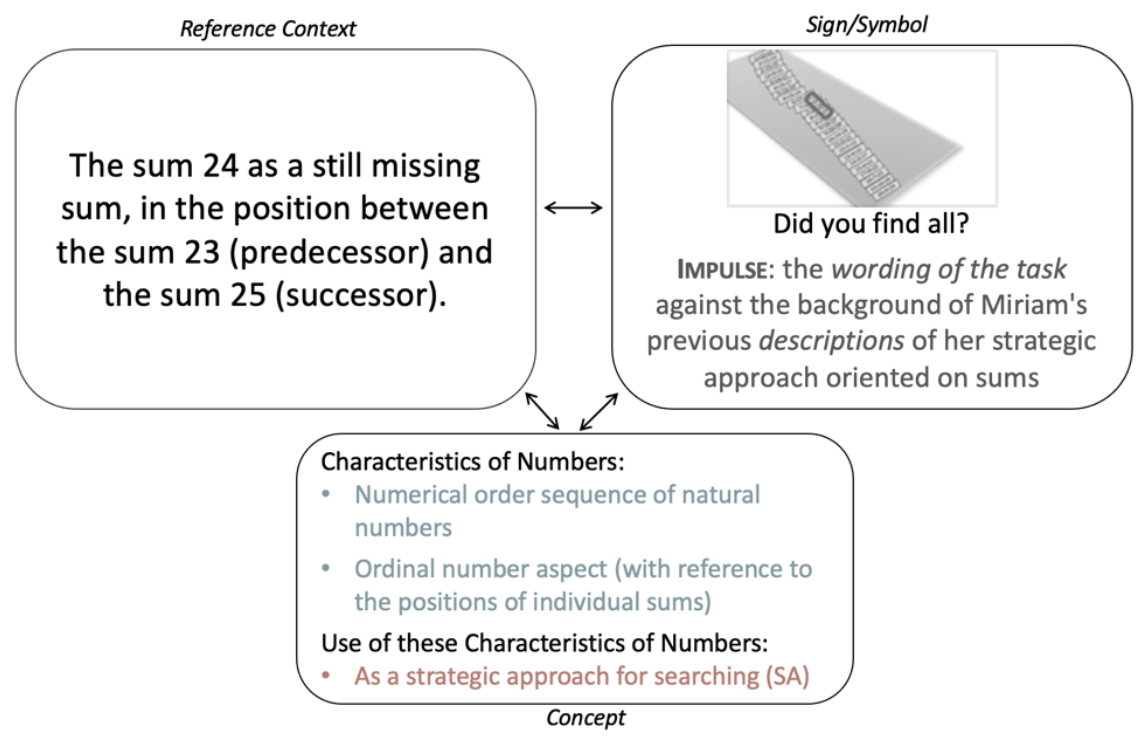

Figure 7. Marina's Interpretation II.

Note. Marina's Interpretation II. Translated, adapted without affecting the meaning and reprinted from Gemeinsame Lernsituationen im inklusiven Mathematikunterricht - Zieldifferentes Lernen am gemeinsamen Lerngegenstand des flexiblen Rechnens in der Grundschule (p. 256), by L. Korten, 2020, Springer Spektrum. Copyright 2020 by Springer Nature. 
Translated, adapted and reprinted with permission from Springer Nature and Copyright Clearance Center.

This reference context of Marina (cf. Figure 7, reference context, upper left) became Miriam's new sign/symbol, which needed explanation and interpretation (cf. Figure 8, sign/symbol, upper right). She argued against Marina's incorrect assumption (Table 2, line 7) and interpreted the sum, 24, as a not missing sum in a regular arithmetic pattern (cf. Figure 8, reference context, upper left). Miriam's interpretation seems to be based on newly perceived relations between numbers $(\mathbf{C E})$ where the sums typically expected (ordinality) were missing in the materials. Consequently, further situational development had taken place (cf. Figure 8, concept). The trigger for this was Marina's incorrect assumption that challenged Miriam to argue against it (cf. Figure 8, IMPULSE, upper right).

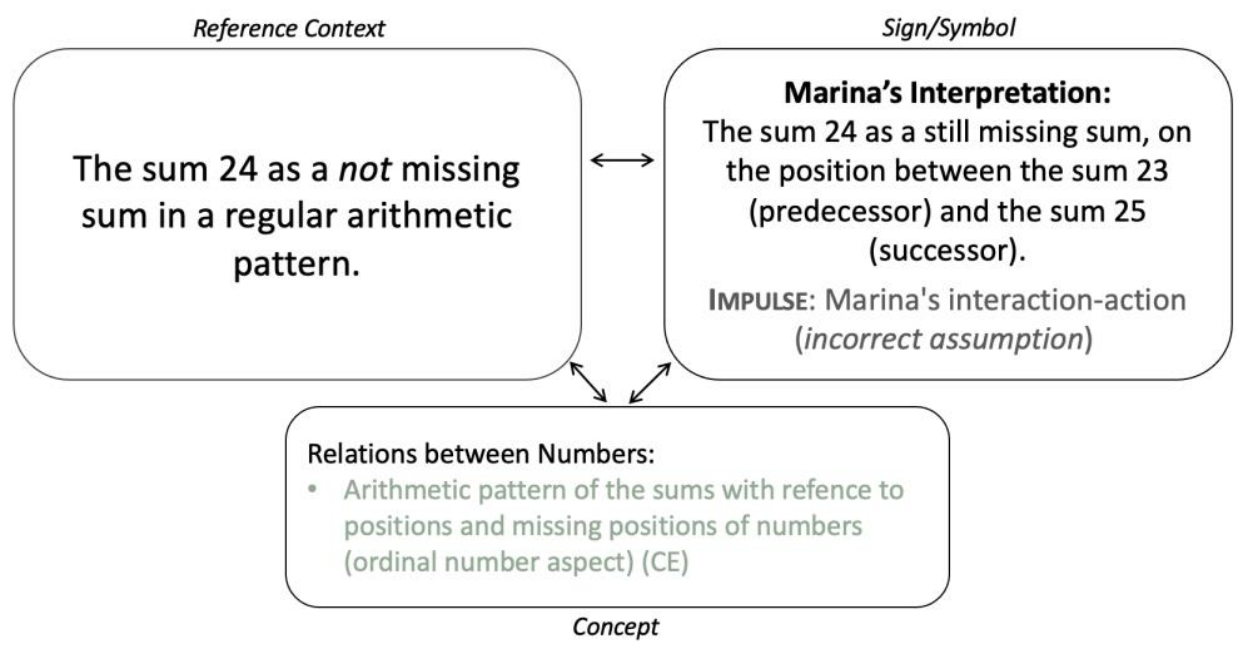

Figure 8. Miriam's Interpretation I.

Note. Miriam's Interpretation I. Translated, adapted without affecting the meaning and reprinted from Gemeinsame Lernsituationen im inklusiven Mathematikunterricht - Zieldifferentes Lernen am gemeinsamen Lerngegenstand des flexiblen Rechnens in der Grundschule (p. 257), by L. Korten, 2020, Springer Spektrum. Copyright 2020 by Springer Nature. Translated, adapted and reprinted with permission from Springer Nature and Copyright Clearance Center.

In the course of argumentation, Miriam discovered relations between the addition problems. She perceived that the equality of two sums results from changing the summands equally in opposite directions (CE). Later she uses these relations between two problems for her advantage: she used them as ,strategic means' for calculating (TS) and as a strategic approach for searching (SA). Consequently, a further, development could be reconstructed (cf. Figure 9, concept). The primary trigger for this development seemed to be 
Marina's incorrect assumption and Miriam's following own engagement in and analysis of the mathematical structure while searching for counterarguments (cf. Figure 9, IMPULSE, upper right). (Due to the length of this report, this further development of Miriam can only be outlined in summary in Figure 9 and drafted without being verified in another transcript.)

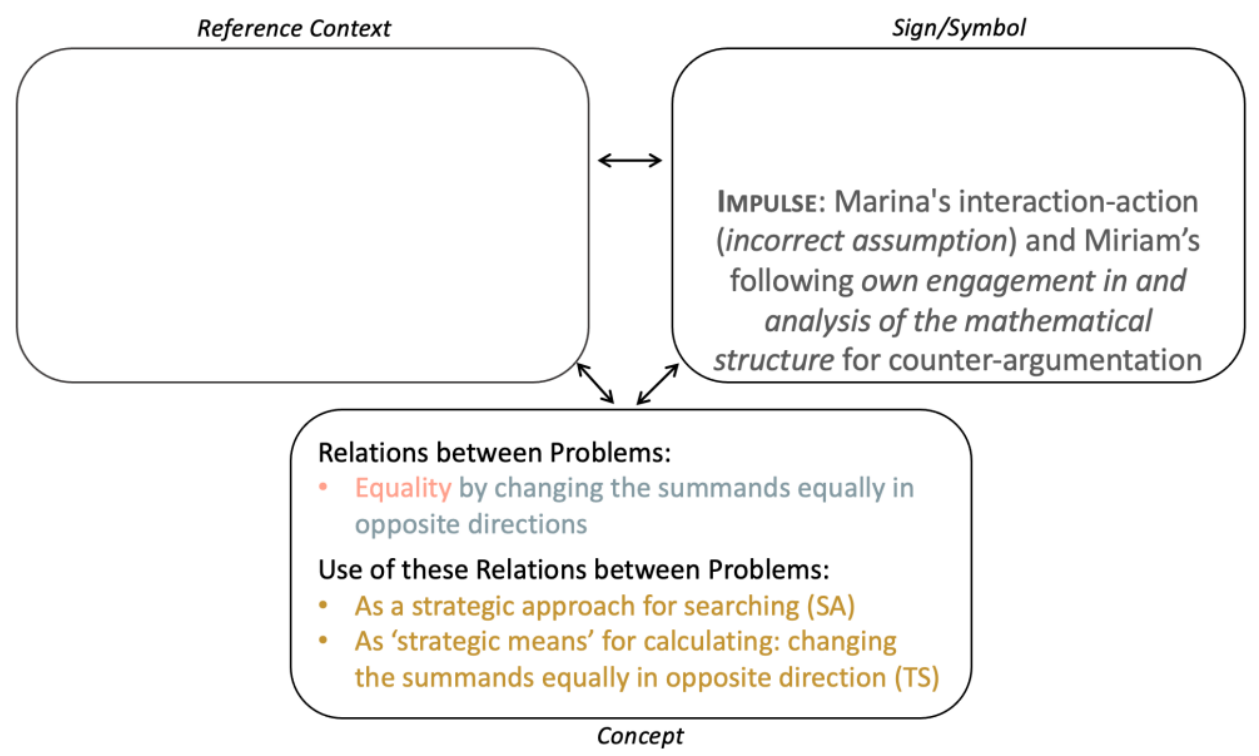

Figure 9. Miriam's Interpretation II.

\section{Overview of Results}

\section{Five Typical Learning Processes (to answer RQ1)}

A closer look at the development of the individual and goaldifferentiated flexible mental calculation processes of all design experiments has made it possible - by using case contrasts and comparative analyses - to identify five typical learning processes. They occurred in phases and combination. A distinction can be made between phases in which

(1) No learning processes can be observed during the encouraged interactivecooperative learning situations and phases in which learning processes occurred regarding the following different aspects:

(2) Cognitive elements (CE) with the focus on the perception of new characteristics and relations of numbers and problems (e. g. Figure 6, 8).

(3) Strategic approaches (SA) for searching for neighboring numbers (e. g. Figure 7).

(4) Tools of solution (TS) with the focus on new 'strategic means' for calculating when solving an addition problem.

(5) Strategic approaches interrelated with tools of solution, with the focus on new 'strategic means' (SA) (TS) (e. g. Figure 9). 
Furthermore, there were the following results of these five typical learning processes:

- Both partners progressed (cf. exemplary analysis).

- Passive phases (1) were temporary and 'time-shifted' learning opportunities. Even though no progress could be observed during these passive phases, the content of interaction was picked up later and seemed to support learning opportunities.

- Children with learning difficulties progressed primarily in terms of cognitive elements at the level of numbers (development of numerical concepts) (2) (cf. Marina in the exemplary analysis).

- Children without learning difficulties developed primarily in terms of cognitive elements and 'strategic means' at the level of numbers and problems (2) (4) (5) (cf. Miriam in the exemplary analysis).

- Children without learning difficulties developed in more aspects overall, concerning cognitive elements (CE), strategic approaches (SA), and tools of solution (TS).

\section{Impulses that can Lead to 'Productive Moments' in the Interaction (to answer RQ3)} interactions.

Three types of impulses could be distinguished in students'

- Interactive impulses. The interaction-action of the partner became an occasion for productive learning processes. These interactive impulses were primarily - but not only - potentially 'productive moments' for children with learning difficulties since they were stimulated by the descriptions and explanations of the partner. They led to rethinking and reflecting (Example, cf. Figures 6, 8, and 9).

- Indirect-didactic impulses. The self-engagement in and the analysis of the mathematical structure became an occasion for productive learning processes. These indirect-didactic impulses were primarily - but not only potentially 'productive moments' for children without learning difficulties (Example, cf. Figure 9).

- Direct-didactic impulses: The wording of the task and the verbal/ nonverbal situational impulses of the teacher became an occasion for productive learning processes. These direct-didactic impulses are potentially 'productive moments' for all children (Example, cf. Figure 7).

Figure 10 (an enhancement of Figure 2) shows on the left side a detailed overview of these impulses that can lead to 'productive moments' in the interaction. They are presented in conjunction with the reconstructed 'key activities' (following Dekker and Elshout-Mohr, 1998) on the right side.

Knowledge about these 'productive moments' and the types of impulses that can produce them can become a helpful and modern template for planning interactive activities that maximize the development of cognitive 
flexibility in mental arithmetic. Especially the knowledge and awareness about the specific direct-didactic, indirect-didactic and interactive impulses, as illustrated in detail in Figure 10 on the left, can support teachers in terms of their lesson planning. Moreover, knowledge and awareness about the different types of specific 'key activities' (Figure 10, right) may also support teachers regarding classroom observation and diagnosis, as they are indicators of productive interactions and reference points for interactive learning processes. (Parts of these exemplary analysis and results were translated and reprinted as regards content from Gemeinsame Lernsituationen im inklusiven Mathematikunterricht - Zieldifferentes Lernen am gemeinsamen Lerngegenstand des flexiblen Rechnens in der Grundschule (p. 225 ff.), by L. Korten, 2020, Springer Spektrum. Copyright 2020 by Springer Nature. Translated and reprinted with permission by a full chapter license from Springer Nature and Copyright Clearance Center.)

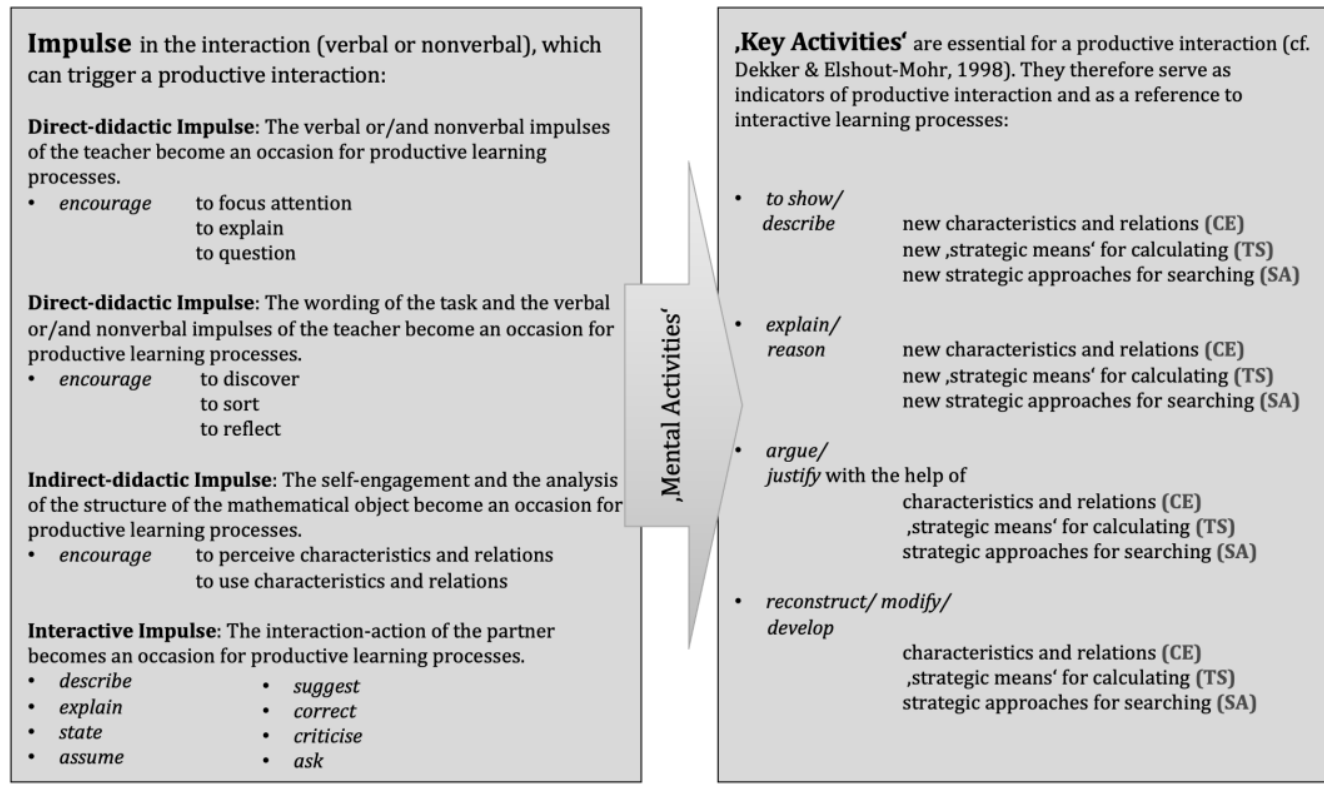

Figure 10. 'Productive Moments' which could be Reconstructed during the Interactive-Cooperative Learning Situations (enhancement of Figure 2)

Note. 'Productive Moments' which could be Reconstructed during the Interactive-Cooperative Learning Situations. Translated and reprinted from Gemeinsame Lernsituationen im inklusiven Mathematikunterricht Zieldifferentes Lernen am gemeinsamen Lerngegenstand des flexiblen Rechnens in der Grundschule (p. 343), by L. Korten, 2020, Springer Spektrum. Copyright 2020 by Springer Nature. Translated and reprinted with permission from Springer Nature and Copyright Clearance Center. 


\section{Discussion}

The data reported here clearly show that student-to-student interactions can be an occasion for productive learning processes regarding flexibility in mental arithmetic. In the context of the reported study, a longer report could have shown that flexible mental calculation competencies developed for all participating learners triggered by interaction, though we are limited here to illustrating an exemplary interaction with one heterogeneous student pairs. With regard to Rathgeb-Schnierer's (2011, cf. Figure 1) domains of calculation processes, as well as the dark grey fields of the model in Figure 4, goal-differentiated developments occurred on levels (a) concerning the perception and reflection of new characteristics and relations of numbers and problems (cognitive element $(\mathbf{C E})$ ), as well as (b) concerning the use and reflection of these characteristics and relations for working out sums with the focus on 'strategic means' for calculating (tools of solution (TS)). I have described which of these learning processes took place and how they were triggered by the interaction.

These findings support the importance of student-to-student communication about arithmetical characteristics and relations for developing flexible calculating competencies. Beyond that, this study emphasizes the potential productiveness of the communication between two children (without the teacher) and the benefit of sharing insights among heterogeneous students about characteristics and relations of numbers and problems. To deepen analysis in the field of cognitive flexibility in the context of interaction, similar studies with different foci on the domains of calculation processes (e. g., differently chosen addition problems, a different operation like subtraction or multiplication, a different method of calculation) should be conducted to investigate the efficacy of student-to-student interactions on cognitive flexibility.

Furthermore, the findings reported here underscore the importance of the connection with other areas of research - here interaction research - in mathematics education. These results are consistent with other studies. They show that successful communication within interactive-cooperative learning situations can contribute to mathematical learning and that the way of interacting is central to the productiveness of learning processes (e. g., Dekker \& Elshout-Mohr, 1998; Häsel-Weide, 2016; Stacey \& Gooding, 1998; Webb, 1989). Even mistakes made during the interaction, like Marina's incorrect assumption about the missing "24," were shown to contribute to improved mathematical reasoning and learning in her arithmetic classroom (for the role of mistakes also see Häsel-Weide, 2017).

The results reported here also provide information for the improvement of the teaching-learning arrangement (level of design), as they allow conclusions about the effectiveness of the learning environment and its design principles to be drawn about consequences for school practice and 
pedagogy. Another consequence for pedagogy that the indirect- and directdidactic impulses have, which are potentially 'productive moments' for all children, is that they emphasize the essential role of the teacher for planning and implementing teaching.

The study reported here has its limitations. In general, research methodological decisions, as well as the theoretical framework, led to the data being collected, analyzed, and interpreted under a certain theoretical approach. Alternative approaches would be conceivable and would possibly lead to different results than those presented here. For the present study, the data were collected in laboratory settings to ensure successful design experiments within a manageable framework, before going into the classroom. Although the laboratory setting recreated the complexity of a peer setting in a classroom, it was still an isolated situation with few disruptive factors and special character, so that the results may not be transferred one-to-one to a class setting. Furthermore, the generalizability of the results of the present study is limited. Only 14 student pairs were analyzed to show exemplary processes. Due to the heterogeneity of the children and the different backgrounds of the classes of origin, it was not possible to achieve generalizability in the sense of empirical statistics. Nevertheless, the analytical induction of a comparative and contrasting case analysis was used to test already developed theories based on new cases and to refine them in the light of new findings.

\section{References}

Cobb, P., Yackel, E., \& Wood, T. (1992). Interaction and learning in mathematics classroom situations. Educational Studies in Mathematics, 23, 99-122.

Dekker, R., \& Elshout-Mohr, M. (1998). A process model for interaction and mathematical level raising. Educational Studies in Mathematics, 36, 303-314.

Gaidoschik, M. (2010). Die Entwicklung von Lösungsstrategien zu den additiven Grundaufgaben im Laufe des ersten Schuljahres [The development of solution strategies for additive tasks in the course of the first school year]. Wien: Universität Wien.

Häsel-Weide, U. (2016). Vom Zählen zum Rechnen - Struktur-fokussierende Deutungen in kooperativen Lernumgebungen [From counting to calculating - structure-focused interpretations in cooperative learning environments]. Wiesbaden: Springer.

Häsel-Weide, U. (2017). Mistakes as occasions for productive interactions in inclusive mathematics classrooms. In T. Dooley \& G. Gueudet (Eds.), Proceedings of CERME 10 (pp. 1292-1299). Dublin: DCU Institute of Education and ERME.

Häsel-Weide, U., \& Nührenbörger, M. (2012). Fördern im Mathematikunterricht [Supporting in mathematics lessons]. In $\mathrm{H}$. 
Bartnitzky, U. Hecker, \& M. Lassek (Eds.), Individuell fördern Kompetenzen stärken in der Eingangsstufe [Individual support Strengthening competences in the first school years]. Frankfurt am Main: Grundschulverband.

Heinze, A., Star, J. R., \& Verschaffel, L. (2009). Flexible and adaptive use of strategies and representations in mathematics education. ZDM Mathematics Education, 41, 535-540.

Klein, A. S., \& Beishuizen, M. (1998). The empty number line in Dutch second grades: Realistic versus gradual program Design. Journal of Research in Mathematics Education, 29(4), 443-464.

Korff, N. (2015). Inklusiver Mathematikunterricht in der Primarstufe: Erfahrungen, Perspektiven und Herausforderungen [Inclusive mathematics teaching in primary schools: experiences, perspectives and challenges]. Baltmannsweiler: Schneider-Verl. Hohengehren.

Korten, L. 2020. Gemeinsame Lernsituationen im inklusiven Mathematikunterricht - Zieldifferentes Lernen am gemeinsamen Lerngegenstand des flexiblen Rechnens in der Grundschule [Common learning situations in inclusive mathematics classrooms - goaldifferentiated learning on the common learning object of flexible arithmetic in primary school]. Wiesbaden: Springer Spektrum.

Krummheuer, G. (2010). Die Interaktionsanalyse [The interaction analysis]. online Fallarchiv-Uni Kassel Schulpädagogik. Last download 01.06.2019: $\quad$ http://www.fallarchiv.uni kassel.de/wpcontent/uploads/2010/07/krummheuer_inhaltsanalyse.pdf

Lorenz, J. H. (2005). Lernschwache Rechner fördern: Ursachen der Rechenschwäche. Frühhinweise auf Rechenschwäche diagnostisches Vorgehen [Promoting children with calculation difficulties: Causes of calculation difficulties. Early indications and diagnostic procedure]. 2. Auflage. Berlin: Cornelsen Scriptor.

Ministerium für Inneres und Kommunales des Landes Nordrhein-Westfalen (Ed.). (2013, November 5). Erstes Gesetz zur Umsetzung der VNBehindertenrechtskonvention in den Schulen

Schulrechtsänderungsgesetz) - Vom 5. November 2013.

MSW. (2008). Richtlinien und Lehrpläne für die Grundschule in NordrheinWestfalen vom Ministerium für Schule und Weiterbildung. Abgerufen am 01.09.2020:

http://www.schulentwicklung.nrw.de/lehrplaene/upload/klp_gs/LP_GS _2008.pdf

Naujok, N. (2000). Schülerkooperation im Rahmen von Wochenplanunterricht. Analyse von Unterrichtsausschnitten aus der Grundschule [Pupil cooperation within the framework of weekly plan lessons. Analysis of lessons from primary school]. Weinheim: Deutscher Studien Verlag. 
Rathgeb-Schnierer, E. (2006). Kinder auf dem Weg zum flexiblen Rechnen. Eine Untersuchung zur Entwicklung von Rechenwegen bei Grundschulkindern auf der Grundlage offener Lernangebote und eigenständiger Lösungsansätze [Children on the way to flexible calculating. An investigation about the development of arithmetic pathways of primary school children on the basis of open learning opportunities and independent solution approaches]. Berlin: Franzbecker.

Rathgeb-Schnierer, E. (2010). Entwicklung flexibler Rechenkompetenzen bei Grundschulkindern des 2. Schuljahrs [The development of flexible mental calculations of second graders], Journal für Mathematikdidaktik, 31, 257-283.

Rathgeb-Schnierer, E. (2011). Warum noch rechnen, wenn ich die Lösung sehen kann? Hintergründe zur Förderung flexibler Rechenkompetenzen [Why counting when I see the solution? Theoretical framework of teaching flexible mental calculation]. In R. Haug \& L. Holzäpfel (Eds.), Beiträge zum Mathematikunterricht 2011 (15-22). Münster: WTM-Verlag.

Rathgeb-Schnierer, E., \& Green, M. (2013). Flexibility in mental calculation in elementary students from different math classes. In B. Ubuz, Ç. Haser, \& M. A. Mariotti (Eds.), Proceedings of the Eighth Congress of the European Society for Research in Mathematics Education (pp. 353-362). Ankara, Turkey: PME and METU.

Rechtsteiner-Merz, C. (2013). Flexibles Rechnen und Zahlenblickschulung. Entwicklung und Förderung von Rechenkompetenzen bei Erstklässlern, die Schwierigkeiten beim Rechnenlernen zeigen [Flexible mental calculation and "Zahlenblickschulung". Development and promotion of numeracy skills of first graders who show difficulties in learning calculating]. Münster: Waxmann.

Rechtsteiner-Merz, C., \& Rathgeb-Schnierer, E. (2016). Flexible mental calculation and "Zahlenblickschulung". In K. Krainer \& N. Vondrová (Eds.), Proceedings of CERME 9 (pp. 354-360). Prague, Czech Republic.

Prediger, S., Gravemeijer, K. P. E., \& Confrey, J. (2015). Design research with a focus on learning processes: An overview on achievements and challenges. ZDM Mathematics Education, 47, 877-891.

Selter, Ch. (2000). Vorgehensweisen von Grundschüler(inne)n bei Aufgaben zur Addition und Subtraktion im Zahlenraum bis 1000 [Procedures of primary school pupils in addition and subtraction tasks in the number range up to 1000]. Journal für Mathematik-Didaktik, 21(3/4), 227258.

Selter, Ch. (2009). Creativity, flexibility, adaptivity and strategy use in mathematics. ZDM Mathematics Education, 41, 619-625. 
Selter, Ch., Walter, D., Walther, G., \& Wendt, H. (2016). Mathematische Kompetenzen im internationalen Vergleich: Testkonzeptionen und Ergebnisse [Mathematical competences in international comparison: test concepts and results]. In H. Wendt, W. Bos, Ch. Selter, O. Köller, K. Schwippert, \& D. Kasper (Eds.), TIMSS 2015: Mathematische und naturwissenschaftliche Kompetenzen von Grundschulkindern im internationalen Vergleich (pp. 79-136). Münster: Waxmann.

Stacey, K., \& Gooding, A. (1998). Communication and learning in smallgroup discussion. In H. Steinbring, M.G. Bartolini Bussi, \& A. Sierpinska (Eds.), Language and communication in the mathematics classroom (pp. 191-206). Reston: National Council of Teachers of Mathematics.

Steinbring, H. (2005). The construction of new mathematical knowledge in classroom interaction - An epistemological perspective. Berlin: Springer.

Steinbring, H. (2015). Mathematical interaction shaped by communication, epistemological constrains and enactivism. ZDM Mathematics Education, 47, 281-293.

Steinke, I. (2000). Gütekriterien qualitativer Forschung [Quality criteria of qualitative research]. In U. Flick, E. von Kardorff, \& I. Steinke (Eds.), Qualitative Forschung. Ein Handbuch (pp. 319-331). Reinbek b. Hamburg: Rowohlt Taschenbuch.

Threlfall, J. (2002). Flexible mental calculation. Educational Studies in Mathematics, 50, 29-47.

Threlfall, J. (2009). Strategies and flexibility in mental calculation. ZDM Mathematics Education, 41, 541-555.

Torbeyns, J., De Smedt, B., Ghesquière, P., \& Verschaffel, L. (2009). Acquisition and use of shortcut strategies by traditionally schooled children. Educational Studies in Mathematics, 71, 1-17.

Verschaffel, L., Luwel, K., Torbeyns, J., \& van Dooren, W. (2009). Conceptualising, investigating and enhancing adaptive expertise in elementary mathematics education. European Journal of Psychology of Education, 24(3), 335-359.

Webb, N. M. (1989). Peer interaction and learning in small groups. International Journal of Educational Research., 13(1), 21-39.

\section{Author:}

Laura Korten

University of Münster, Department of Mathematics Education and Computer

Science Education, Fliednerstraße 21, 48149 Münster, Germany

Email: laura.korten@uni-muenster.de 